\title{
Seasonal variability in sediment profiles beneath fish farm cages in the Mediterranean
}

\author{
Ioannis Karakassis*, Manolis Tsapakis, Eleni Hatziyanni \\ Institute of Marine Biology of Crete, PO Box 2214, GR-71003 Heraklion, Crete, Greece
}

\begin{abstract}
The chemical and physical (water content) changes in sediment profiles beneath and around fish farm cages were investigated on a seasonal basis in Cephalonia Bay, Greece, a relatively enclosed marine area with weak currents and silty substrate. The surface concentrations and the vertical distribution of the sedimentary variables studied (organic matter, organic carbon/nitrogen, chlorophyll, phaeopigments, water content and total phosphorus) varied substantially with distance from the cages and with season. The black-coloured top layer (farm sediment) showed high concentrations of organic matter, phaeopigments and total phosphorus as well as high water content while the compact subsurface layer had concentrations close to (or lower than) those at the control site. The thickness of the farm sediment layer under the cages varied with season, while in all seasons it decreased rapidly with increasing distance from the cages.
\end{abstract}

KEY WORDS: Fish farms - Sediment chemistry $\cdot$ Vertical profiles Mediterranean

\section{INTRODUCTION}

The proliferation of the aquaculture in the coastal zone during the last $20 \mathrm{yr}$ has caused concern for impacts on critical environmental variables (GESAMP 1990) and therefore information on such impacts has been extensively studied and reviewed during the last 10 yr (Gowen \& Bradbury 1987, Gowen 1991, Iwama 1991, Wu 1995), the common point being that most of the detectable effects on marine ecosystems are related to sediment beneath the fish farms. Several authors have reported the presence of a loose and flocculent black sediment under fish cages (Hall et al. 1990, Angel et al. 1995), commonly named 'fish farm sediment' (Holmer 1991). This sediment is characterized by low values of redox potential (Hargrave et al. 1993), high content of organic material (Hall et al. 1990, Holmer 1991) and accumulation of nitrogenous and phosphorous compounds (Holby \& Hall 1991, Hall et al. 1992). These changes in the physical and chemi-

\footnotetext{
·E-mail: jkarak@imbc.gr
}

cal characteristics of the seabed induce conspicuous changes in the structure of the benthic communities (O'Connor et al. 1989, Weston 1990, Pocklington et al. 1994). Most of the above cited papers are related to the salmon industry in Northern Europe and North America, while very little is known about such impacts in the southern areas of the northern hemisphere including the Mediterranean (Munday et al. 1994), where a continuously expanding farming industry of sea bream and sea bass has been established in the coastal zone. However in warm, oligotrophic seas with a microtidal marine environment such as the Mediterranean, some deviations from the general patterns could be expected as a result of higher metabolic rates, different temporal patterns in water movement and differences in the structure of plankton and benthic communities.

Even less is known on the temporal variability of the environmental impacts that are directly related to the variance in food supply due to the different temperature of the ambient water (Goddard 1996). Seasonal variability in food supply determines the seasonal variability in environmental loss of carbon, nitrogen and phosphorus towards the seabed and the water column 
according to well-studied mass balance models (Gowen \& Bradbury 1987, Hall et al. 1990, 1992, Holby \& Hall 1991). However the resulting seasonal pattern in nutrient availability in the water column is anticipated to differ from the 'natural' seasonal pattern. In the case of non-impacted marine ecosystems, nutrients are abundant during winter and early spring and they are gradually depleted at the surface waters during the warm season, whereas in mariculture-impacted ecosystems most of the nutrient loss (and consequently most of the nutrient enrichment in the water column) occurs during the warm period (i.e. summer and early autumnj. Among the nutrients, phosphorus is of prime importance for the Mediterranean, which is considered, unlike most of the world's ocean, as a P-limited sea (Krom et al. 1991). The understanding of seasonal dynamics of sedimentation of phosphorus from fish farms in the Mediterranean is an important element for the prediction of the long-term impacts of aquaculture on the coastal environment.

We examined the temporal variability in sedimentary variables at different distances from fish farm cages in Cephalonia Bay in the SE Ionian Sea through the analysis of vertical profiles. A simple numerical index (summarizing in 1 value patterns in vertical profiles) is proposed for the investigation of the impacts of the fish farms on the seabed.

\section{MATERIALS AND METHODS}

Study area. Cephalonia Bay is a rather enclosed area, which is connected with the open sea through a small opening at the southern end. The fish farm investigated was the first ever established in Greek waters (in 1981) and one of the largest in the Mediterranean, producing ca $1000 \mathrm{t}$ of sea bream and sea bass per year.

The particular unit monitored was a group of 10 cages, each with dimensions of $15 \mathrm{~m}$ by $15 \mathrm{~m}$ by $12 \mathrm{~m}$ depth, arranged in 5 pairs in a north-south direction. The water depth at this site varied between 16 and $20 \mathrm{~m}$, the mean current velocity being $3.6 \mathrm{~cm} \mathrm{~s}^{-1}$ with a maximal value of $18 \mathrm{~cm} \mathrm{~s}^{-1}$ recorded within a 2 yr deployment of current meters (P. G. Drakopoulos, Institute of Marine Biology of Crete, unpubl. data). According to these measurements, water moved southward more than $70 \%$ of the time. The particular unit had been in operation for 4 yr when our investigation started, producing ca $140 \mathrm{t}$ of gilthead sea bream Sparus aurata per year.

Sampling strategy. In order to determine the seasonal change in the thickness of the farm sediment layer as well as the variability in vertical profiles of chemical variables, sampling stations were established under the cages $(0 \mathrm{~m})$ as well as at 5,10 and $25 \mathrm{~m}$ distances from the edge of the cages downstream in the main current direction. A control site with similar depth $(21 \mathrm{~m})$ and substrate type was established $1 \mathrm{~km}$ upstream. Samples were collected during 4 sampling trips (October 1996, February, May and July 1997) by SCUBA divers using $20 \mathrm{~cm}$ long core tubes of $5 \mathrm{~cm}$ internal diameter. When arriving at the surface, cores were immediately deep frozen (at $-20^{\circ} \mathrm{C}$ ) until subsequent analysis. Stations at distances of 5 and $10 \mathrm{~m}$ from the cages were sampled only during the last 2 trips. Replicate samples were also collected at the $0,25 \mathrm{~m}$ and control stations in order to determine variability within samples. In order to minimize effects of pseudoreplication, cores at stations located in the vicinity of the farm were taken at least $1 \mathrm{~m}$ (perpendicular to the main current direction) apart from each other, while those at the control station were taken randomly at least $5 \mathrm{~m}$ apart from each other. In the laboratory the cores were sliced into horizontal $11 \mathrm{~cm}$ thick) layers.

Redox potential ( $E$ h) profiles at $2 \mathrm{~cm}$ intervals were also determined in larger core samples by means of an electrode standardized with Zobell's solution (Zobell 1946).

Chemical analyses. The water content of the sediment (SWC) was determined as the weight loss after drying at $80^{\circ} \mathrm{C}$ until constant weight (approximately 20 to $30 \mathrm{~h}$ ). Total phosphorus was determined in the dried samples, which were homogenized by grinding and digested with a mixture of perchloric and nitric acid (Burton \& Riley 1956, Sturgeon et al. 1982). The concentration of $\mathrm{P}$ was determined colorimetrically as molybdate reactive phosphorus (Strickland \& Parsons 1972). Total organic carbon and nitrogen were determined in part of the samples using a Perkin Elmer 2400 CHN Elemental Analyzer according to the procedure described by Hedges \& Stern (1984). Organic material (loss on ignition. LOI) was determined as the weight loss of the dried sample after combustion for $6 \mathrm{~h}$ at $500^{\circ} \mathrm{C}$ (Kristensen \& Andersen 1987). Sediment contents in chlorophyll (chl) and phaeopigments were determined according to the method described by Yentsch \& Menzel (1963) using a Turner fluorometer (model 112) and 90\% acetone as diluter.

Data analysis. In order to obtain a measure of the vertical variability for each sedimentary environmental variable, the coefficient of variation $[\mathrm{CV}(k)]$ was calculated as the ratio of standard deviation over the mean of a variable $(k)$ at all depths of the core cast, i.e.:

$$
C V(k)=\frac{\mathrm{SD}(k)}{\bar{k}}
$$

The concept behind this calculation is that nonimpacted sediments are expected to show relatively 

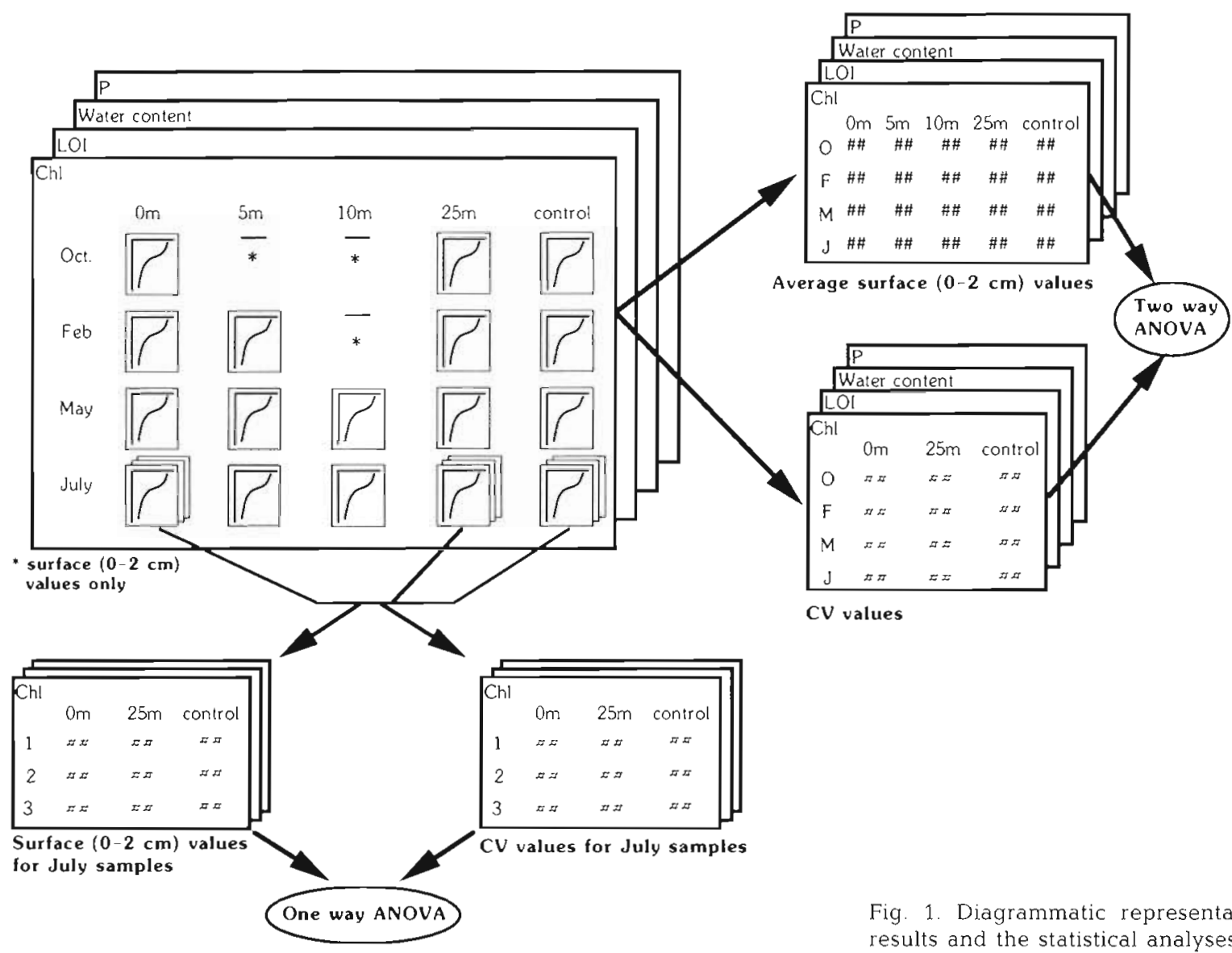

Fig. 1. Diagrammatic representation of the results and the statistical analyses performed

lower variability with depth due to low sedimentation rate and to the bioturbating activity of macrofauna. CV is a dimensionless value standardized by mean and therefore allows for comparison of variability across different variables.

A diagrammatic representation of the statistical analyses performed on the data obtained is presented in Fig. 1. Analysis of variance (ANOVA) was used to determine the overall significance of differences among samples and a post hoc Tukey test for multiple comparisons between groups of samples assembled according to the significant factors. One-way ANOVA was used to test for differences among stations sampled with replication in July. Two-way ANOVA /distance by season) was used to test for differences in the entire data set.

\section{RESULTS}

Redox potential showed similar patterns during all seasons (Fig. 2). At the control site positive values were recorded at least down to $-4 \mathrm{~cm}$ from the sediment surface, while very low values were measured from the sediment surface at the station beneath the cages.
The station located at $25 \mathrm{~m}$ from the edge of the farm presented intermediate values at all depths, with positive values at the surface except for July 1997 when negative values were recorded in the entire cast. In this particular season, Eh values at the $25 \mathrm{~m}$ station were closer to those at the station beneath the cages than to the respective ones at the control site.

Results on the vertical distribution of the SWC, LOI, chloroplastic pigments and phosphorus are presented in Fig. 3. The vertical distribution of all variables revealed conspicuous differences with depth, the higher concentrations being recorded at the surface layers of the station under the cages. At the $25 \mathrm{~m}$ station, the vertical pattern and the values measured were in most cases close to those at the control site.

The depth of the farm sediment was determined as the zone where maximal change in SWC was found between 2 sequential layers [d(SWC)]. The results (Fig. 4) showed differences among sampling seasons: the thickness of the surface layer was found to be $5 \mathrm{~cm}$ in October at the end of the warm season, it decreased to $2 \mathrm{~cm}$ in February (indicating a limited recovery process), it increased again to $4 \mathrm{~cm}$ in May and reached 5 to $6 \mathrm{~cm}$ in July. Neither the control site nor the $25 \mathrm{~m}$ station presented such peaks for the respec- 


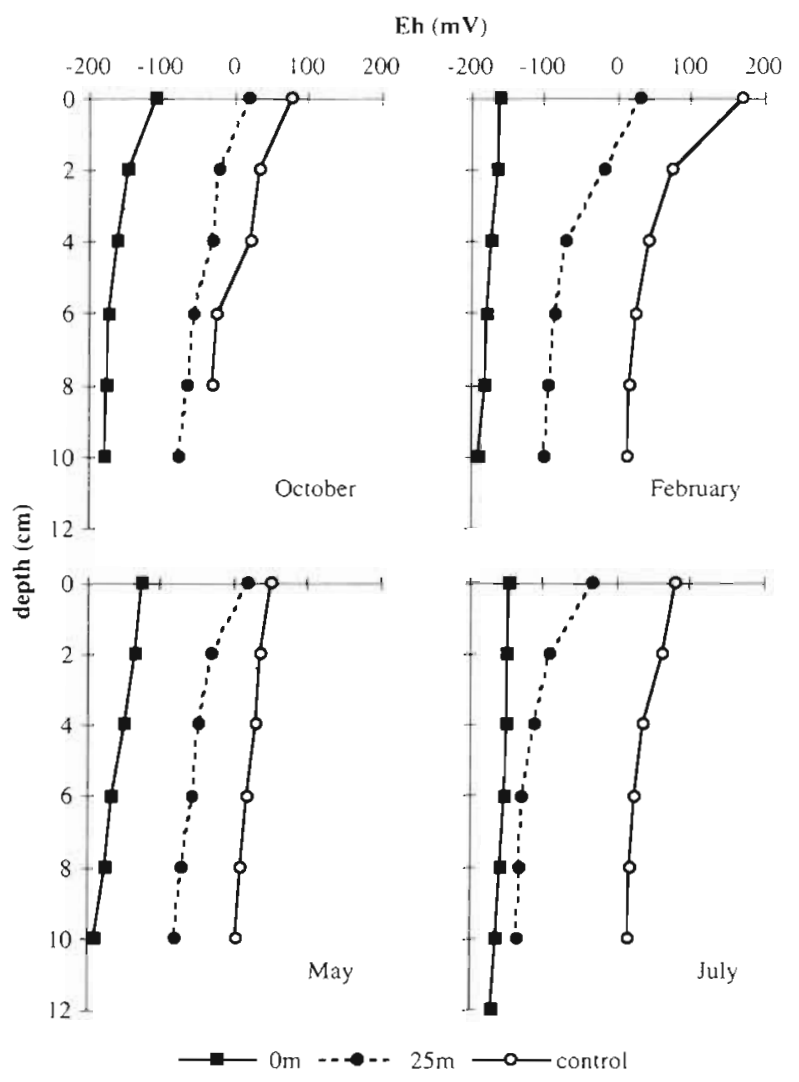

Fig. 2. Redox potential profiles at the stations beneath the cages, at $25 \mathrm{~m}$ distance and at the control site for the $4 \mathrm{sam}$ pling seasons

tive curves, both of these stations showed maximal values at the surface and subsequently decreased with small fluctuations. A similar pattern was evident for the change in organic material concentrations [d(LOI)] also presented in Fig. 4.

In order to assess the horizontal extent of the impact, surface values ( 0 to $2 \mathrm{~cm}$ ) were used for stations under the cages, at 5, 10 and $25 \mathrm{~m}$ as well as at the control site (Fig. 5). The 2-way ANOVA (Table 1 ) revealed significant differences in concentrations of the measured environmental variables with distance but not with season. The subsequent post hoc test did not show any significant differences between the control and the intermediate stations $(5,10,25 \mathrm{~m})$, while there were significant differences between the station beneath the cages and the other (control and intermediate) stations for several variables.

The CV (Fig. 6) was calculated for 3 stations $10 \mathrm{~m}$, $25 \mathrm{~m}$ and control) during all the sampling seasons. Different patterns in the vertical distribution of each variable are reflected in the values of CV. The 2-way (season by distance) analysis of variance (Table 2 ) revealed again significant differences with distance only. The Tukey post hoc test (among distance categories) showed significant differences between the station under the cages and the other two for SWC and LOI, whereas in the case of phosphorus and phaeopigments no significant differences were found between the stations at 0 and $25 \mathrm{~m}$ from the cages. In all the variables examined, no significant difference was detected between the station at $25 \mathrm{~m}$ and the control. No post hoc analysis was performed for chl since no significant effect was found for either season or distance.

Analysis of vertical profiles by means of $\mathrm{CV}$ using 3 replicates at each station $(0 \mathrm{~m}, 25 \mathrm{~m}$ and control) was performed for SWC, LOI and chl. Results (Table 3) showed that $\mathrm{CV}$ could detect significant differences

Table 1. Results of 2-way ANOVA for surface values for all the sampling seasons. $p<0.05, \cdots p<0.01$. ns: not significant

\begin{tabular}{|c|c|c|c|c|c|c|c|c|c|}
\hline \multirow[t]{2}{*}{ Variable } & \multirow{2}{*}{$\begin{array}{l}\text { Source of } \\
\text { variability }\end{array}$} & \multirow[t]{2}{*}{$F$} & \multirow[t]{2}{*}{$\mathrm{df}$} & \multirow[t]{2}{*}{$p$} & & \multicolumn{4}{|c|}{ Tukey post hoc test } \\
\hline & & & & & & $0 \mathrm{~m}$ & $5 \mathrm{~m}$ & $10 \mathrm{~m}$ & $25 \mathrm{~m}$ \\
\hline \multirow[t]{4}{*}{ Water content } & Season & 0.66 & 3 & ns & $5 \mathrm{~m}$ & ns & & & \\
\hline & Distance & 5.96 & 4 & 0.013 & $10 \mathrm{~m}$ & $\cdot$ & ns & & \\
\hline & & & & & $25 \mathrm{~m}$ & $\cdot$ & ns & ns & \\
\hline & & & & & Control & $\cdot$ & ns & ns & ns \\
\hline \multirow[t]{4}{*}{ LOI } & Season & 0.32 & 3 & ns & $5 \mathrm{~m}$ & $\cdot$ & & & \\
\hline & Distance & 6.05 & 4 & 0.007 & $10 \mathrm{~m}$ & “ & ns & & \\
\hline & & & & & $25 \mathrm{~m}$ & $\cdot$ & ns & ns & \\
\hline & & & & & Control & $\cdot$ & ns & ns & ns \\
\hline \multirow[t]{4}{*}{ Phosphorus } & Season & 0.81 & 3 & ns & $5 \mathrm{~m}$ & ns & & & \\
\hline & Distance & 5.43 & 4 & 0.010 & $10 \mathrm{~m}$ & ns & ns & & \\
\hline & & & & & $25 \mathrm{~m}$ & $\dot{.}$ & ns & ns & \\
\hline & & & & & Control & $\because$ & ns & ns & ns \\
\hline \multirow[t]{4}{*}{ Chl } & Season & 1.29 & 3 & ns & $5 \mathrm{~m}$ & ns & & & \\
\hline & Distance & 4.32 & 4 & 0.022 & $10 \mathrm{~m}$ & $\cdot$ & ns & & \\
\hline & & & & & $25 \mathrm{~m}$ & ns & ns & ns & \\
\hline & & & & & Control & . & ns & ns & ns \\
\hline
\end{tabular}




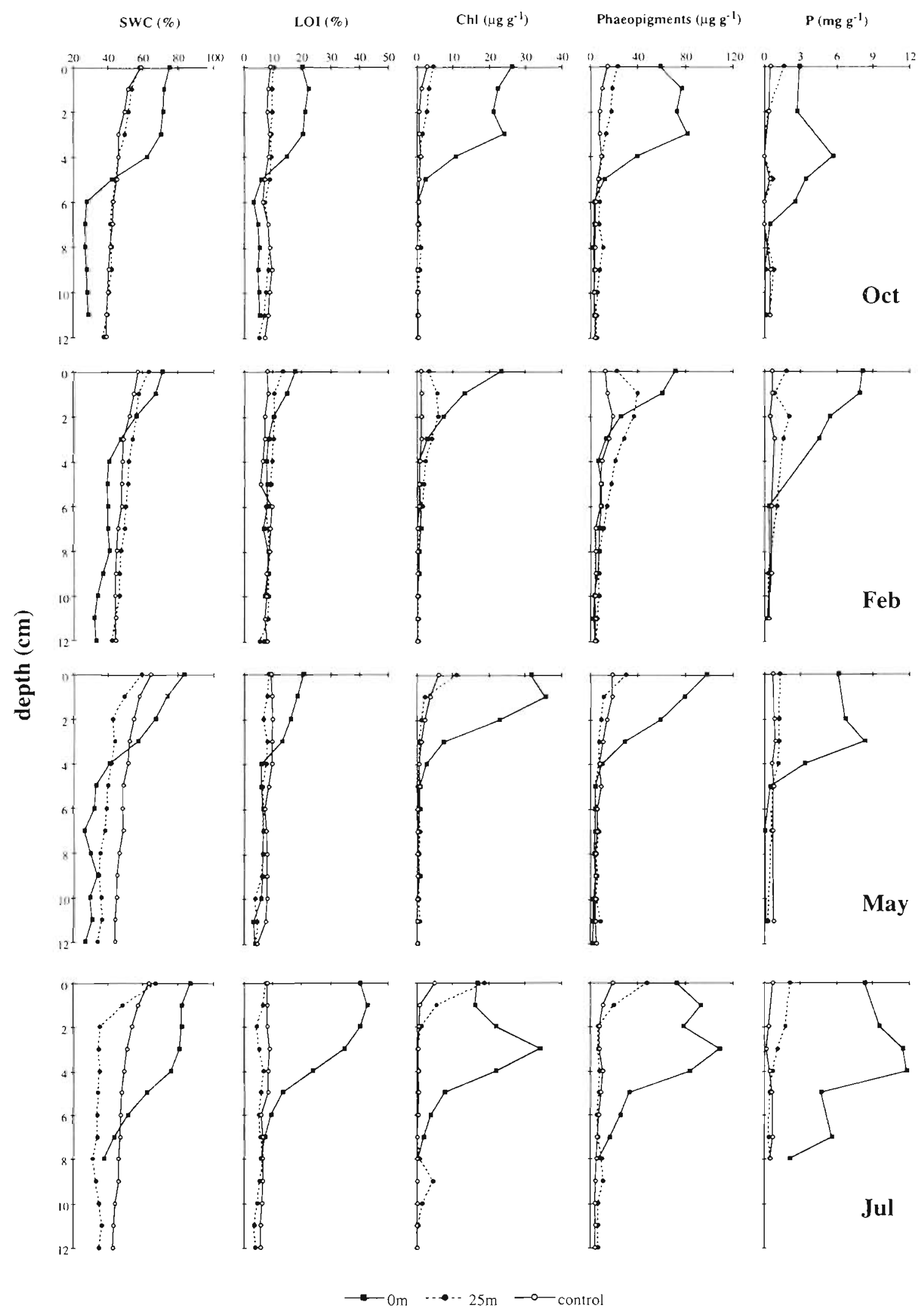

Fig. 3. Vertical distribution of sediment variables in core profiles beneath the cages, at $25 \mathrm{~m}$ distance and at the control site. SWC: sediment water content; LOI: organic material 

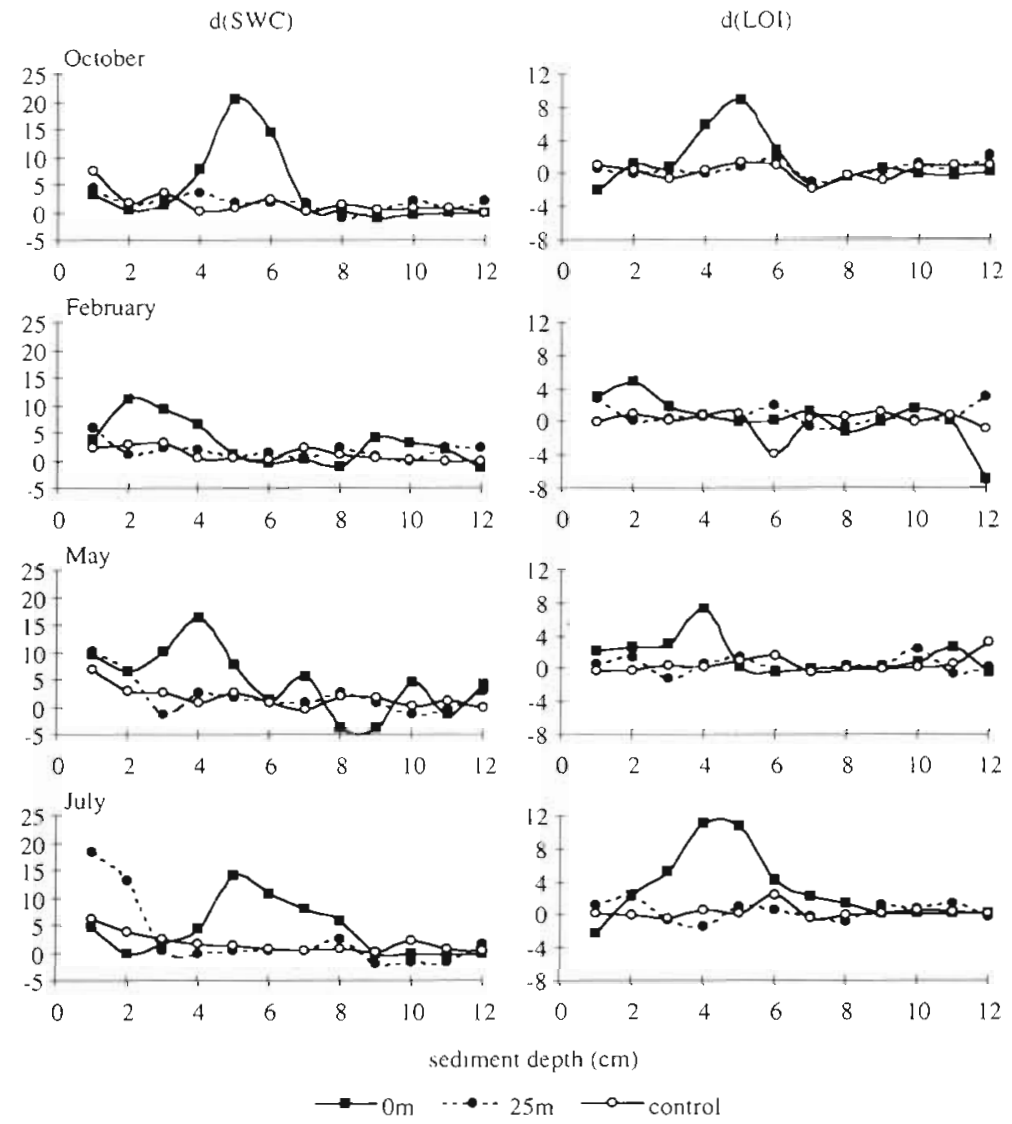

Fig. 4. Determination of farm sediment depth for each season as the depth corresponding to the maximum value of $d(\mathrm{SWC})$ and $d(\mathrm{LOI})$

between the cages and the other stations for SWC and LOI, whereas in the case of chl only the station at $25 \mathrm{~m}$ was significantly different from the other two.

LOI provides a measure of the organic content of the sediment, however this value is a good estimator of the organic carbon in highly enriched sediments whereas it overestimates organic material in samples with low organic content due to pyrolysis of carbonates and other combustible inorganic compounds. The surface LOI values reported above (Fig. 5) for the station under the cages and at the $25 \mathrm{~m}$ station seem to be higher than those at the control station by a factor of 5 for samples taken in July. However results obtained for samples through CHN analysis (Fig. 7) showed that this factor is approximately 13 for organic carbon and 15 for organic nitrogen.

\section{DISCUSSION}

The results of the present study revealed a fluctuation of the farm sediment thickness throughout the year at the station beneath the cages which seems to be related to the food input which had a similar temporal fluctuation, the minimum (in January) being $50 \%$ of the period's maximum in June (D. Troyanos pers. comm.). The lower values measured during February indicate that a limited recovery process takes place during the winter period due to the coupling of low food input with increased efficiency in mineralization during winter (Gilbert et al. 1997). Strong wind-driven currents during this period of the year could also be responsible for sediment resuspension, removing part of the accumulated waste. However the investigation of change through ANOVA did not show any seasonal effect either for surface or for CV values. This discrepancy is probably due to the main characteristics of the 2-way ANOVA which is

Table 2. Results of 2-way ANOVA for CV values for all the sampling seasons. $p<<0.05, \cdots p<0.01$ ns: not significant

\begin{tabular}{|c|c|c|c|c|c|c|c|}
\hline \multirow[t]{2}{*}{ Variable } & \multirow{2}{*}{$\begin{array}{l}\text { Source of } \\
\text { variability }\end{array}$} & \multirow[t]{2}{*}{$F$} & \multirow{2}{*}{$\mathrm{df}$} & \multirow[t]{2}{*}{$\mathrm{p}$} & & \multicolumn{2}{|c|}{ Tukey post hoc tes } \\
\hline & & & & & & $0 \mathrm{~m}$ & $25 \mathrm{~m}$ \\
\hline \multirow[t]{2}{*}{ Water content } & Season & 0.815 & 3 & ns & $25 \mathrm{~m}$ & $\cdot$ & \\
\hline & Distance & 13.696 & 2 & 0.006 & Control & $\cdots$ & ns \\
\hline \multirow[t]{2}{*}{ LOI } & Season & 0.785 & 3 & ns & $25 \mathrm{~m}$ & $\cdots$ & \\
\hline & Distance & 28.054 & 2 & 0.001 & Control & $\cdot \cdot$ & ns \\
\hline \multirow[t]{2}{*}{ Phosphorus } & Season & 0.102 & 3 & ns & $25 \mathrm{~m}$ & $\mathrm{~ns}$ & \\
\hline & Distance & 9.299 & 2 & 0.015 & Control & . & ns \\
\hline \multirow[t]{2}{*}{ Phaeopigments } & Season & 0.463 & 3 & ns & $25 \mathrm{~m}$ & ns & \\
\hline & Distance & 5.417 & 2 & 0.045 & Control & $\cdot$ & ns \\
\hline \multirow[t]{2}{*}{ Chal } & Season & 0.463 & 3 & ns & - & - & - \\
\hline & Distance & 5.417 & 2 & ns & - & - & - \\
\hline
\end{tabular}



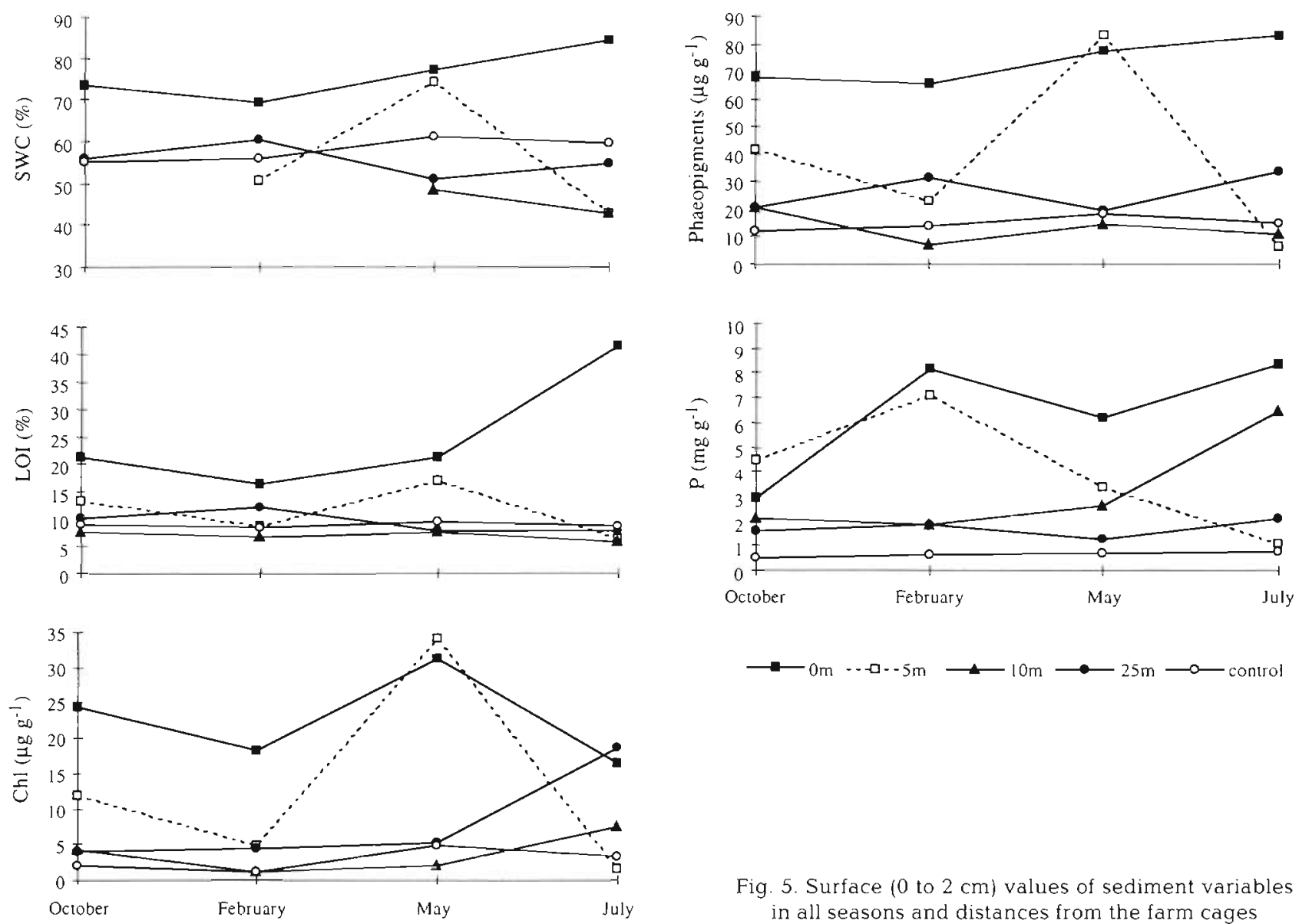

able to detect significant differences only when factor 1 induces similar response (increase or decrease) in all the values of all the levels of factor 2 . However this is unlikely in the case of seasonal trends examined in our data and in particular for surface values. The values recorded here as concentrations ( $w: w)$ do not correspond to similarly deposited sediments since the sedimentation rate under the cages and even at the station

at $25 \mathrm{~m}$ varies dramatically, the amount of settling material at the $25 \mathrm{~m}$ station, determined by means of sediment traps, being 5 to $10 \%$ that of the station under the cages (Tsapakis unpubl. data). Moreover the summer sedimentation of the (naturally deposited) organic material at the control station is expected to be (and it was found to be) minimal while for the same period the concentration of organic material under the

Table 3. Results of 1-way ANOVA for CV and surface values for the replicated sampling in July. ${ }^{*} p<0.05, \cdots p<0.01$. ns: not significant

\begin{tabular}{|c|c|c|c|c|c|c|c|c|}
\hline & \multicolumn{4}{|c|}{ CV } & \multicolumn{4}{|c|}{ Surface values } \\
\hline & & & $0 \mathrm{~m}$ & $25 \mathrm{~m}$ & & & $0 \mathrm{~m}$ & $25 \mathrm{~m}$ \\
\hline Chl & $\begin{array}{l}F=20.052 \\
\mathrm{df}=2,6 \\
\mathrm{p}=0.002\end{array}$ & $\begin{array}{r}25 \mathrm{~m} \\
\text { Control }\end{array}$ & $\begin{array}{l}\cdots \\
\text { ns }\end{array}$ & - & $\begin{array}{l}F=10.909 \\
\mathrm{df}=2.6 \\
\mathrm{p}=0.010\end{array}$ & $\begin{array}{r}25 \mathrm{~m} \\
\text { Control }\end{array}$ & $\begin{array}{l}\text { ns } \\
\text { ns }\end{array}$ & $\because$ \\
\hline LOI & $\begin{array}{l}F=36.249 \\
\mathrm{~d} f=2,6 \\
\mathrm{p}=0.000\end{array}$ & $\begin{array}{r}25 \mathrm{~m} \\
\text { Control }\end{array}$ & $\begin{array}{l}\cdots \\
\cdots\end{array}$ & ns & $\begin{array}{l}F=80.801 \\
\mathrm{df}=2.6 \\
\mathrm{p}=0.000\end{array}$ & $\begin{array}{r}25 \mathrm{~m} \\
\text { Control }\end{array}$ & $\ddot{~}$ & ns \\
\hline Water content & $\begin{array}{l}F=8.752 \\
\mathrm{~d} f=2,6 \\
\mathrm{p}=0.017\end{array}$ & $\begin{array}{r}25 \mathrm{~m} \\
\text { Control }\end{array}$ & ns & ns & $\begin{array}{l}F=49.874 \\
\mathrm{df}=2.6 \\
\mathrm{p}=0.000\end{array}$ & $\begin{array}{r}25 \mathrm{~m} \\
\text { Control }\end{array}$ & $\begin{array}{l}. . \\
. \cdot\end{array}$ & ns \\
\hline
\end{tabular}



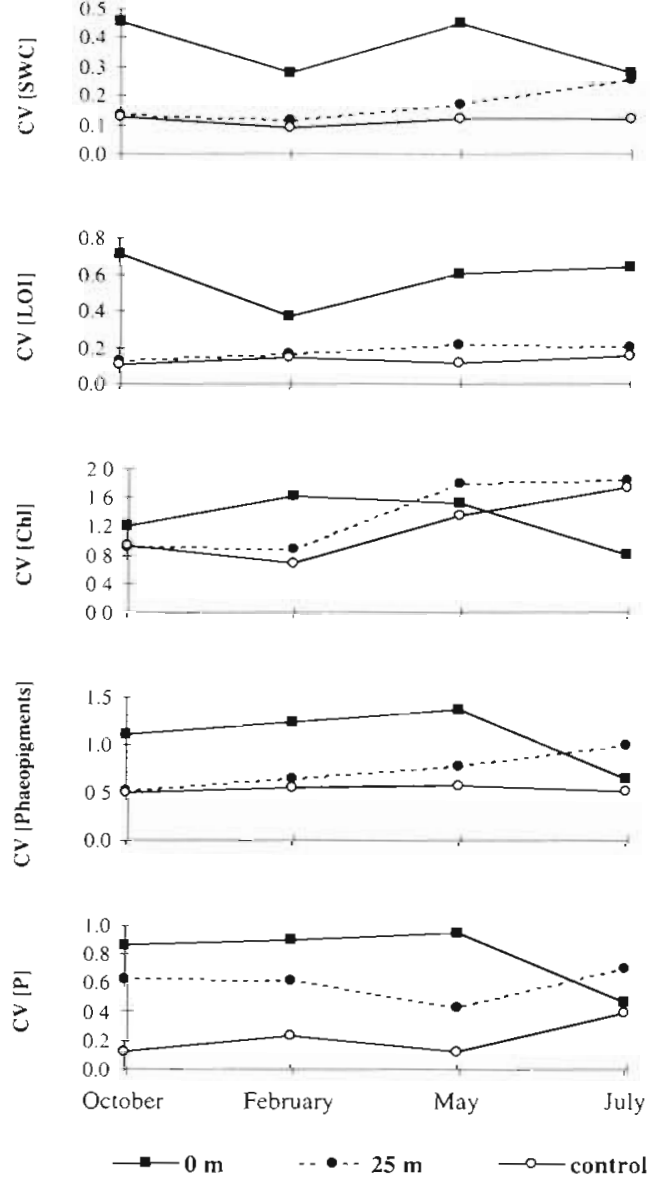

Fig. 6. Values of sediment vertical variability index (CV) for 3 sampling stations in all the sampling seasons

cages is maximal due to the intensification of the temperature-dependent feeding process. A different seasonal pattern has been reported by Gilbert et al. (1997) for the impact of shellfish farming on the sedimentary variables in a Western Mediterranean lagoon. These differences are attributed to the different characteristics of the 2 farming practices, the shellfish farming depending on in situ plankton production whereas cage fish farming depends on exogenous organic input highly regulated by the ambient water temperature.

The extent of the seabed area impacted by fish farming activities varies in general with current velocity and depth according to the model proposed by Gowen \& Bradbury (1987). Significant impacts have been reported at distances of $100 \mathrm{~m}$ from the cages but in general it seems that this impact is a highly localized phenomenon not exceeding 20 to $50 \mathrm{~m}$ (Beveridge 1996). Our results are in accordance with this view since only the station beneath the cages was consistently different from the control site for all the variables measured. However it seems that the intermediate stations were impacted up to a certain point since
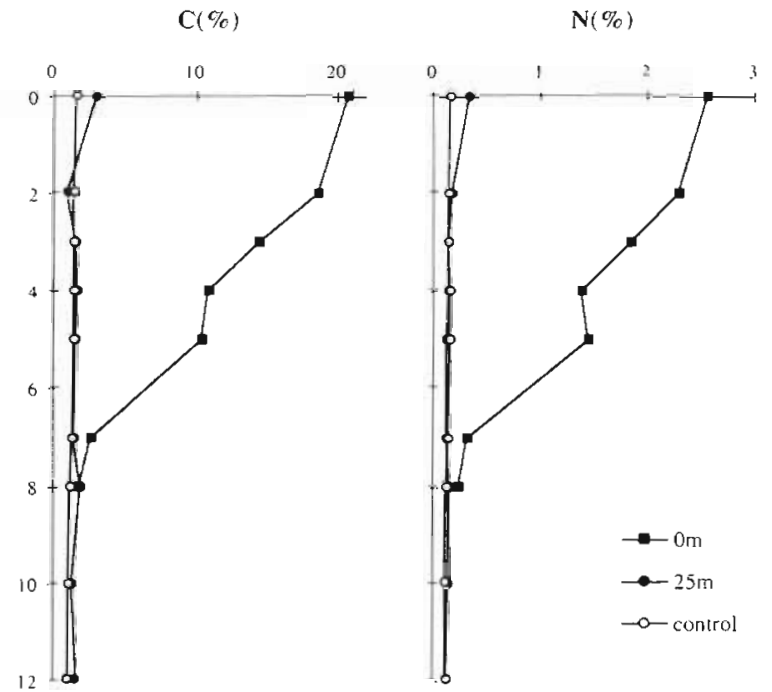

Fig. 7 Results of CHN analysis for organic carbon and nitrogen for samples collected during July 1997

at least for some of the environmental variables they presented no significant difference from either the control or the impacted station. The detected impact on the intermediate stations could be due to either direct settling of small particles, carried longer distances by the current, or to resuspension and resettling by strong wind-driven currents

There were conspicuous differences among environmental variables in terms of both enrichment factors and vertical distribution. This is no surprise since each of these variables is related to different processes impacted by the presence and the function of the farm.

The vertical distribution of water content in the sediment followed the same pattern in all the sampling periods. The loose surface layer under the cages contained up to $95 \%$ water, exceeding that at the control station by at least $20 \%$. Deeper in the sediment a rapid change with depth marks the limit of this recently deposited layer. In this deeper zone the sediment is more compact than at the control station, perhaps due to the absence of the bioturbating activity of the macrofauna since the accumulation of food and faeces during the warm season results in highly anoxic conditions under the cages which have been shown to reduce the available space for macrofaunal organisms (Hatziyanni et al. 1997). Kupka-Hansen et al. (1991) have reported a farm sediment thickness up to $30 \mathrm{~cm}$ (with 60 to $90 \%$ SWC) in Western Norway, indicating that no larger fauna (>5 mm) was found when thickness exceeded $20 \mathrm{~cm}$.

The concentration of organic material (as estimated by means of LOI), as shown by CHN results, is a poor descriptor of the farm impact, at least as far as the comparison to the reference site is concerned. How- 
ever this method allows comparisons between seasons and it has been used by many authors so far for the assessment of such impacts although the methodology used in the literature is anything but standard. Lower LOI values ( 15 to $20 \%$ ) have been reported for shellfish farms in the Western Mediterranean (Gilbert et al. 1997), concentrations up to $10 \%$ were found under a sea bream farm in the Gulf of Aqaba (Angel et al. 1995) while levels similar to those in the present study have been reported for salmonids in Norway (15 to $47 \%$ ) by Kupka-Hansen et al. (1991) and for rainbow trout in Denmark (18 to $24 \%$ ) by Holmer \& Kristensen (1992).

The concentration of $\mathrm{chl}$ in the sediment is related either to phytobenthos or to the sedimentation of phytoplankton cells from the water column. However in Cephalonia Bay and particularly around the farm cages, no filamentous algae or other benthic plants were found and the high turbidity reduces the amount of radiation reaching the seabed. Therefore it could be considered that the entire chlorophyll content is related to the sedimentation as also indicated by the low ratio of chl:phaeopigments. The pronounced increase in chl content beneath the cages could be attributed to higher phytoplankton production in the cages as a result of the increase in ammonium and phosphate coupled with increased sedimentation rates due to the significant decrease in current velocity within the cages (Inoue 1972 in Iwama 1991).

The pronounced sediment anoxia makes the sediment unsuitable for macrofaunal organisms and especially infaunal deposit feeders that could digest sedimenting phytoplankton cells, while the presence of mussels on the ropes and floating structures of the cages is likely to contribute to the increased sedimentation of undigested phytoplankton material through the production of pseudofaeces. Numerous studies have revealed such an increased production of pseudofaeces with increased concentration of phytoplankton in the water column (Bayne et al. 1976). The repackaging of phytoplankton cells in larger particles could produce a different pattern in the dispersion of particles under the cages than that predicted by Silvert (1994) since pseudofaeces tend to be larger in size than single phytoplankton cells, but smaller than unconsumed food pellets or sea bream faecal pellets. Therefore sinking rates of pseudofaeces are expected to be lower than the average particles sedimenting from the cages and consequently they could be transported further away by the water current. This could be the reason for the relatively high concentrations of pigments found in the sediments at the $25 \mathrm{~m}$ distance station.

Phosphorus concentrations at the $25 \mathrm{~m}$ distance stations showed consistently higher values (by a factor of 1.6 to 3.3 ) at the surface sediment layers than respec- tive concentrations at the control station. This difference was even higher at the station below the cages, exceeding the respective concentrations at the control site by 6 to 13 times. In general total $P$ concentrations showed a progressive increase in sediment loading with time, which is consistent with the information provided by the fish farmer concerning the intensification of feeding process in this unit. The vertical profiles of phosphorus concentrations under the cages in Cephalonia Bay showed a pattern similar to that found by Holby \& Hall (1991) for a rainbow trout farm in Gullmar Fjord, Sweden, although the values reported by these authors for the surface layers were considerably higher (15 $\mathrm{mg} \mathrm{g}^{-1}$ ) despite the cessation of the feeding activity during the winter months (i.e. December to March) in this particular farm (Hall et al. 1990).

The results of the present paper support the observation by Holby \& Hall (1991) for the accumulation of phosphorus in the farm sediment. Fig. 3 shows that unlike other variables, phosphorus load in the sediment constantly increases despite the smaller or larger fluctuations at the surface. Previously conducted measurements at the same sites (Karakassis et al. 1997) indicated that maximum loading occurs during late autumn and therefore it is expected that during October 1997 the accumulation of phosphorus would increase even more. The fact that a large amount of phosphorus tends to be buried in the sediment is an important issue since it implies that this part of the loss to the environment is not available for phytoplankton growth and therefore there is a lower risk of triggering algal blooms in P-limited marine environments such as the Mediterranean Sea. However in order to arrive at safe conclusions concerning phosphorus release in the warm Mediterranean sediments, specific experiments should be conducted for the measurement of phosphate fluxes.

The detection of change through the study of vertical profiles of the sediment water content was proved to be an efficient method in discriminating differences along the organic enrichment gradient. The CV index showed relatively low variability within replicates (standard deviation was less than $29 \%$ of the mean, as opposed to $36 \%$ for surface values).

The present study emphasizes the need for investigating patterns in vertical profiles as a means for the assessment of fish farming impacts. The measurement of surface values alone, although useful for the assessment of the size of the impact, may not provide adequate information on the dynamic processes related to the accumulation of waste material beneath the cages. Some of the environmental variables fand in particular concentrations) may be relatively constant in time while the depth of the farm sediment could vary considerably. 
Acknowledgements. The authors thank the manager and the personnel of Cephalonia Fisheries S.A. and in particular Akis Miniatis for their assistance during the sampling. The authors also thank Richard Gowen and 4 anonymous reviewers for helpful comments on the manuscript. This study is part of the project 'Interactions of aquaculture and the marine environment' financed by the Greek General Secretariat for Research and Technology in the frame of the second Operational Programme for R\&T

\section{LITERATURE CITED}

Angel DL, Krost P. Gordin H (1995) Benthic implications of the net cage aquaculture in the oligotrophic Gulf of Aqaba. In: Rosenthal H, Moav B, Gordin H (eds) Improving the knowledge base in modern aquaculture. Eur Aquacult Soc Spec Publ 25:129-173

Bayne BL, Thompson RJ, Widdow's J (1976). Physiology: I. In: Bayne BL (ed) Marine mussels: their ecology and physiology. Cambridge Univ Press, Cambridge

Beveridge MCM. (1996) Cage aquaculture. Fishing News Books, Blackwell, Oxford

Burton JD, Riley JP (1956) Determination of soluble phosphate, and total phosphorus in sea-water and of total phosphorus in marine muds. Mikrochim Acta 9:1350-1365

GESAMP (1990) The state of the marine environment. UNEP Regional Seas Reports and Studies 115

Gilbert F. Souchy P, Bianchi M. Bonin P (1997) Influence of shellfish farming activities on nitrification, nitrate reduction to ammonium and dentrification at the water-sediment interface of the Thau lagoon, France. Mar Ecol Prog Ser 151:143-153

Goddard S (1996) Feed management in intensive aquaculture. Chapman \& Hall, New York

Gowen RJ (1.991) Aquaculture and the environment. In: De Pauw N, Joyce J (eds) Aquaculture and the environment. Eur Aquacult Soc Spec Publ 16:23-48

Gowen RJ, Bradbury NB (1987) The ecological impact of salmonid farming in coastal waters: a review. Oceanogi Mar Biol Annu Rev 25:563-575

Hall POJ, Anderson LG, Holby O, Kollberg S, Samuelsson $\mathrm{MO}$ (1990) Chemical fluxes and mass balances in a marine fish cage farm. I. Carbon. Mar Ecol Prog Ser 61:61-73

Hall POJ, Holby O, Kollberg S, Samuelsson MO (1992) Chemical fluxes and mass balances in a marine fish cage farm. IV. Nitrogen. Mar Ecol Prog Ser 89:81-91

Hargrave BT, Duplisea DE, Pfeiffer E, Wildish DJ (1993) Seasonal changes in benthic fluxes of dissolved oxygen and ammonium associated with marine cultured Atlantic salmon. Mar Ecol Prog Ser 96:249-157

Hatziyanni E, Papadopoulou KN, Plaiti W, Maidanou M. Karakassis I (1997) The structure of macrobenthic communities in three coastal areas of intensive fish-culture. Proc 5th Hellenic Symp Oceanogr Fish 2:223-226

Hedges JI, Stern JH (1984) Carbon and nitrogen determination of carbonate containing solids. Limnol Oceanogr 29 : $657-663$

Holby O, Hall POJ (1991) Chemical fluxes and mass balances

Editorial responsibility: Otto Kinne (Editor)

Oldendorf/Luhe, Germany in a marine fish cage farm. Il. Phosphorus. Mar Ecol Prog Ser 70:263-272

Holmer M (1991) Impacts of aquaculture on surrounding sediments: generation of organic-rich sediments. In: De Pauw N, Joyce J (eds) Aquaculture and the environment. Eur Aquacult Soc Spec Publ 16:155-175

Holmer M, Kristensen E (1992) Impact of fish cage farming on metabolism and sulfate reduction of underlying sediments. Mar Ecol Prog Ser 80:191-201

Iwama GI (1991) Interactions between aquaculture and the environment. Crit Rev Environ Control 21:177-216

Karakassis I, Tsapakis E, Zivanovic S (1997) Spatial and temporal variability in sediment characteristics in the area of three commercial fish farms. Proc 5th Hellenic Symp Oceanogr Fish 2:211-214

Kristensen E, Andersen FØ (1987) Determination of organic carbon in marine sediments: a comparison of two CHNanalyzer methods. J Exp Mar Biol Ecol 109:15-23

Krom MD, Kress N, Brenner S, Gordon L.I (1991) Phosphorous limitation of primary productivity in the eastern Mediterranean Sea. Limnol Oceanogr 36:424-432

Kupka-Hansen P, Pittman K, Ervik A (1991) Organic waste from marine fish farms-effects on the seabed. In: Mäkinen $T$ (ed) Marine aquaculture and environment. Nordic Council of Ministers, Copenhagen, p 105-119

Munday BW, Eleftheriou A, Kentouri M, Divanach P (1994) Quantitative statistical analysis of the literature concerning the interaction of the environment and aquacultureidentification of gap and lacks. J Appl lchthyol 10:319-325

O'Connor BDS, Costelloe J, Keegan BF, Rhoads DC (1989) The use of REMOTS technology in monitoring coastal enrichment resulting from mariculture. Mar Pollut Bull 20: $384-390$

Pocklington P, Scott DB, Schaffer CT (1994) Polychaete response to different aquaculture activities. In: Dauvin JC, Laubier L, Reish DJ (eds) Actes de la 4ème Conférence internationale des Polychètes. Mem Mus Natn Hist Nat 162:511-520

Silvert W (1994) Modelling benthic deposition and impacts of organic matter loading. In: Hargrave BT (ed) Modelling benthic impacts of organic enrichment from marine aquaculture. Can Tech Rep Fish Aquat Sci 1949:1-18

Strickland JD, Parsons TR (1972) A practical handbook of seawater analysis. Bull Fish Res Bd Can 167

Sturgeon RE, Desaulniers JAH, Berman SS, Russell DS (1982) Determination of trace metals in estuarine sediments by graphite-furnace atomic absorption spectrometry. Analytica Chim Acta 134:283-291

Weston DP (1990) Quantitative examination of macrobenthic community changes along an organic enrichment gradient. Mar Ecol Prog Ser 61:233-244

Wu RSS (1995) The environmental impact of marine fish culture: towards a sustainable future. Mar Pollut Bull 31. $159-166$

Yentsch CS, Menzel DW (1963) A method for the determination of phytoplankton chlorophyll and phaeophytin by fluorescence. Deep Sea Res 10:221-231

Zobell CE (1946) Studies on redox potential of marine sediments. Bull Am Assoc Petrol Geol 30:477-513

Submitted: September 23, 1997; Accepted: November 11, 1997 Proofs received from author(s): January 19, 1998 